\title{
Elite forms of willow-leafed pear Pyrus salicifolia Pall. in the steppe zone conditions of the Southern Urals as a seed rootstock for pear
}

\author{
A.I. Lokhova*, and E.M. Feshchenko \\ Orenburg Experimental Station of Horticulture and Viticulture - Branch of the Federal State \\ Budgetary Scientific Institution "Federal Scientific Breeding and Technological Center of \\ Horticulture and Garden Nursery", 460041 Orenburg, Russia
}

\begin{abstract}
The article presents the results of studying the forms of the willow-leafed pear Pyrus salicifolia Pall. of second generation on winter resistance, drought resistance, trees condition, seed productivity. Research was carried out in 2018-2020 on the basis of the Orenburg branch of the Federal Research Center of Horticulture in accordance with standard methods. 2002 planting elite forms of P. salicifolia - 7-19, 7-21, 7-23, 7-24, $7-25,7-26,7-27,7-28,7-29$ were studied. The aim of the research was to study adaptive potential with seed productivity and selection of $\mathrm{P}$. salicifolia forms with the greatest severity of these traits for seed rootstocks use. Comprehensive study of seed productivity and indicators of climatic conditions adaptability allowed to establish that the forms 7-19, 7-24 and 729 were characterized by the best indicators, which can be recommended as pear seed rootstocks in the steppe zone conditions of the Southern Urals.
\end{abstract}

\section{Introduction}

Pear crop is known in most of Russia - from the Caucasus to the Far East, along with other seed crops. Its value lies in a high degree of fruits' taste quality, the content of biologically active substances, vitamins, essential micronutrients. Pear fruits contain arbutin, which is used in therapeutic prevention for kidney and liver diseases [1, 2].

According to the report of the Federal Service of State Statistics, the gross harvest of seed crops in 2019 in all farms amounted to 2.17 million tons: 918.2 thousand tons - in agricultural organizations, 190.9 thousand tons - in farms and 1.07 million tons - in household plots of the population. According to the Ministry of Agriculture of the United States, in 2016 the leading position in the production of pears was taken by China (19.3 million tons), the second place belongs to the European Union (2.28 million tons), the third place - the United States (707 thousand tons).

Despite its profitability, today industrial pear plantings in Russia amount to only 5\% [3]. Pear crop in the Orenburg region has no industrial significance.

\footnotetext{
* Corresponding author: aliya.makaeva@list.ru
} 
Pear is a relatively new and sparsely spread garden crop for the Orenburg region [4]. In Orenburg, Orsk and other settlements, barely studied varieties imported from Europe can be found, which have not received widespread distribution $[5,6]$. In the Urals, pear is involved in the breeding process after 1931, when the Ural zone fruit and berry experimental station was founded in Chelyabinsk (today - Southern-Ural Scientific and Research Institute of Horticulture and Potato Growing — branch of the FSBSI UrFANIC UrD RAS) [7]. New varieties became the result of breeding work in the Urals, Siberia and the Far East. Krasnobokaya, Mif and a number of other varieties grown in the Orenburg region do not reach world standards by many criteria: fruit is characterized by tart taste, pulp properties indicate participation of the Ussurian pear in their origin ( Pyrus ussuriensis Maxim). In Orenburg region, pear crop has twice lower yield compared to apple trees $[5,6]$. A comprehensive approach is needed to optimize the functioning of pear gardens in extremely continental conditions, which implies, first of all, the correct selection of adapted varieties and rootstocks allowing to maximize the potential crop productivity realization.

To date, the development of modern horticulture is aimed at finding clone rootstocks accelerating pear varieties fruiting, limiting growth and having optimal economic and biological traits [8]. In Europe, pear varieties are mainly reproduced using quince rootstock (Cydonia oblonga). According to Brewer L.R. and Palmer J.W. (2011), there is an insufficiently wide range of clone rootstocks for breeding pears in Europe that would be easily and completely compatible with grafting, did not suffer from chlorosis and low winter resistance. Pear seedlings are also used, mainly common pears (Pyrus communis). Occasionally, other Pyrus L. species are found, e.g. P. calleryana, P. ussuriensis or P. betulifolia [9-12]. For example, in his work, Stern R.A. points to the studies' results on compatibility, heat and drought resistance of $P$. communis pear rootstock forms of OHF and BP 1 series, clone seedler Pyrus betulifolia of Israeli selection [13, 14].

Information on rootstock for pear in the Southern Urals is not enough to form a scientific justification for $P$. salicifolia application as seed rootstock. Deficiency of ecologically adapted rootstock is a limiting factor that hinders further spread of pear crop in the Orenburg region. The search for adaptive pear rootstocks with a complex of valuable economic and biological traits has been relevant for a long time. The roodstock serves as "the foundation of the fruit tree", according to I.V. Michurin (1948), who recommended using Ussuri pear (Pyrus ussuriensis Maxim.), as a rootstock as the most winter-proof. This feature contributed to the expansion of the Ussuri pear in the territory of North Asia and on the foothill plateau of North America [15].

Ussuri pear (P. ussuriensis Maxim.) is used in the Orenburg region as a zoned rootstock with its disadvantages: not sufficiently adapted to the arid conditions of the Southern Urals, grafts are characterized by high growth strength and late tree entry into the fruiting period. Also, P. ussuriensis is incompatible with some European varieties. Willow-leafed pear Pyrus salicifolia Pall. is more adapted to the arid conditions of the Orenburg region as it has high drought resistance, as well as salt resistance and relative frost resistance [16-18].

Kuznetsov P.V. (1938, 1941), Apoyan L.A. (1969), Trusevich G.V. (1973), Savin E.Z. et al. $(2013,2019,2020)$ [18-24] were engaged in the study of the willow-leafed pear as rootstock.

Proceeding from the stated above, it is necessary to select rootstock for pear reproduction in the conditions of the Southern Urals adapted to the regional conditions (on the example of the Orenburg region). Consequently, the work on the study of willow-leafed pear seed rootstock forms is relevant.

The purpose of the study was to distinguish promising winterproof productive rootstock forms of willow-leafed pear, the most adapted to the arid conditions of the Orenburg region for their use as seed rootstock. 


\section{Materials and methods}

The research was conducted on the basis of the Orenburg branch of the FSC of Horticulture in 2018-2020. The garden was laid out in spring 2002 with the aim of testing the scionrootstock combinations to isolate the most adaptive pear seed forms and to test them in free form for winter resistance, drought resistance, seed productivity. The scheme of planting on the experimental site: $6 \mathrm{~m}$ between rows, $4 \mathrm{~m}$ between plants.

Objects of research: elite forms of willow-leafed pear of the second generation - 7-19, 7$21,7-23,7-24,7-25,7-26,7-27,7-28,7-29$. The control was the grafting form of the Ussuri pear 4-6.

The research was carried out in accordance with the "Program and Methods of Variety Study of Fruit, Berry, and Nut Crops", methodological recommendations of VNIIS named after Michurin [25, 26]. Winter resistance, general trees condition by field method, drought resistance according to physiological parameters of the water regime in laboratory conditions, [27] seed productivity were studied on stool of the willow-leafed pear.

Calendar dates of fruit harvesting fell on the II-III decade of October. The yield from one tree, the average weight of fruits, the yield of seeds from one fruit, the weight of 1000 seeds [28] were determined. Statistical reliability of differences in the willow-leafed pear forms on drought resistance was estimated on the basis of the limit water loss by the single-factor dispersion analysis method; two-factor dispersion analysis without repetition was used for mathematical experimental data processing on seed productivity using the Microsoft Office Excel 10 analysis package, where A is form, B - year, and cluster analysis by Ward in Statistica 10.

The climate of the Southern Urals is characterized as extremely continental, which is justified by the periodic occurrence of severe snowless winters and hot summer periods with unstable and insufficient atmospheric precipitation regime. During the period of research, weather and climatic conditions were heterogeneous, which allowed to objectively assess the adaptability degree of rootstock forms.

The winter of 2017-2018 was moderate, with a small amount of snow. In January, the height of the snow cover was $9 \mathrm{~cm}$ with an average perennial value of $29 \mathrm{~cm}$. The soil freezing amounted to $150 \mathrm{~cm}$, and the soil temperature in the arable layer $(20 \mathrm{~cm})$ was $-15^{\circ} \mathrm{C}$ (norm $13^{\circ} \mathrm{C}$ ). The summer period was hot and dry. From April to September $170 \mathrm{~mm}$ of precipitation fell in Orenburg. The amplitude in the maximum air temperature fluctuations was $8^{\circ} \mathrm{C}$ (from 33 to $40^{\circ} \mathrm{C}$ ). Relative humidity for the summer period was $56.1 \%$.

The winter of 2018-2019 was moderate with snow cover up to $34.3 \mathrm{~cm}$ in Orenburg. The minimum temperature was within $-30{ }^{\circ} \mathrm{C}$. The soil freezing was insignificant $-94 \mathrm{~cm}$ at a norm of $114 \mathrm{~cm}$. The average daily temperature of the 2019 growing season was close to the annual average, as opposed to rainfall, which had deviations in June and July: $5.9 \mathrm{~mm}$ and $105 \mathrm{~mm}$ respectively at a norm of $35 \mathrm{~mm}$ [3]. Relative air humidity in June was 53,3\%, in August - 60\%.

The winter of 2019-2020 was milder with sufficient snow cover $-38 \mathrm{~cm}$ (norm $-31 \mathrm{~cm}$ ). The minimum temperature dropped to $-25^{\circ} \mathrm{C}$, and in the region - to $-28{ }^{\circ} \mathrm{C}$. No spring frosts were observed, the preservation of flower buds was $35 \%$ higher compared to the previous year, generative buds' laying was more intense due to the fruiting frequency of pear trees. These factors can explain the trend to increase yields in 2020 .

The growing season of 2020 was hot and dry. The air temperature rose up to $40{ }^{\circ} \mathrm{C}$, and on the soil - up to $68^{\circ} \mathrm{C}$. Relative humidity in Orenburg was $53 \%$ and the number of days with relative humidity below $30 \%$ amounted to 109 . The rainfall in July and August was below the perennial averages $-7 \mathrm{~mm}$ and $12 \mathrm{~mm}$ with a norm of $35 \mathrm{~mm}$ and $33 \mathrm{~mm}$ respectively [3]. 
Soil cover of the Orenburg branch of the FSC of Horticulture - Southern chernozem, humus content - 2.7-3.0\%, mobile phosphorus forms - $18.4 \mathrm{mg} / \mathrm{kg}$, nitrogen $-96.6 \mathrm{mg} / \mathrm{kg}$, exchange potassium - $358.6 \mathrm{mg} / \mathrm{kg} \mathrm{kg}$. Experimental plot is boharic with the use of agrotechnics generally accepted in the Orenburg region [28].

\section{Results and discussion}

The potential for pear crop adaptability in the Orenburg region is limited by two key factors - winter resistance and drought resistance. Periodical winters with critical negative temperatures lead to significant damage or death of the above-ground vegetative part of the tree. The actualization of winter resistance potential depends not only on winter period weather conditions, but also on the state of plants during the growing season and the transition period between the state of rest and vegetation [29]. According to E.Z. Savin (2019), until 2016 the willow-leafed pear had low productivity $(1-6 \mathrm{~kg} /$ tree $)$ due to root system freezing in winter 2005-2006 with a degree of 2.5 points, the after-effect of these winter conditions lasted on yield for 4 years. In the future, another group of limiting factors affected the plants - precipitation deficit, frosts of the spring period 2015, high air and soil temperatures during the growing season [24]. During the years of research (2018-2020), when assessing the winter resistance of willow-leafed pear stools in the field, no significant damage was observed. In the winter periods of 2017-2018 and 2018-2019, the temperature lowered to $30 \ldots-32^{\circ} \mathrm{C}$, the following damage was revealed in all forms of willow-leafed pear: wood by 1-2 points, bark and buds - $1-1.5$ points, but all forms of willow-leafed pear have fully recovered and began to grow actively, which indicates their high adaptation degree to growing conditions. During deep rest, the winter conditions of 2019-2020 were milder and no damage was noted. The condition of plants was estimated on average for 3 years by $4-5$ points (Figure 1).

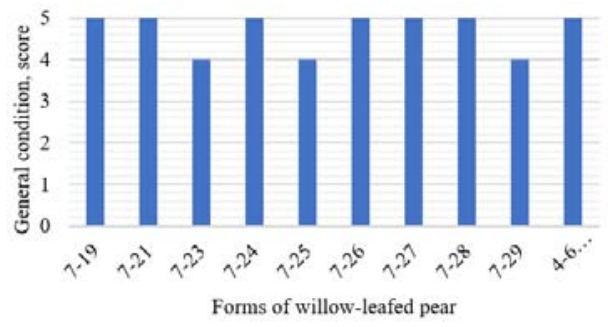

Fig. 1. General condition of willow-leafed pear forms for 2018-2020

Analyzing the study results of drought-resistance by the water regime parameters, it should be noted that under identical growing conditions, the forms' reaction rate to heat and moisture supply depends on genotype features.

The following forms were characterized by higher water content on average over the years of research compared to other samples: 4-6 Ussuri (C) (56.0\%), 7-24 (60.3\%), 7-29 (60.4\%) (Table 1). This indicates that these forms have sufficient moisture in the tissues subject to drought. By hydration, all willow-leafed pear forms $(<59,9 \%)$ possess low drought-resistance degree, except for abovementioned forms 7-24 and 7-29, which are characterized by an average degree (60.0-69.9\%). The amount of water in the leaves is directly dependent on the moisture supply during the growing season. Thus, considering the conditions of excess humidity in 2019 , the water content was within $60.0-70.3 \%$ in forms 7-19, 7-23, 7-24, 7-25, 7-28, 7-29 and 4-6 Ussuri (C). More arid conditions of 2020 contributed to an increase in the variation scope of this indicator: from $36.3 \%$ in form $7-27$ to $55.8 \%$ in form $7-24$. 
Table 1. Indicators of leaves water supply of willow-leafed pear forms for 2018-2020,\%

\begin{tabular}{|c|c|c|c|c|c|}
\hline Specimen & Year & Leaf water supply, $\%$ & Specimen & Year & $\begin{array}{l}\text { Leaf water } \\
\text { supply, \% }\end{array}$ \\
\hline \multirow[t]{3}{*}{$7-27$} & 2018 & 40.7 & \multirow[t]{3}{*}{$7-23$} & 2018 & 55.0 \\
\hline & 2019 & 46.7 & & 2019 & 60.2 \\
\hline & 2020 & 36.3 & & 2020 & 48.5 \\
\hline \multicolumn{2}{|l|}{ Average } & 41.2 & \multicolumn{2}{|l|}{ Average } & 54.6 \\
\hline \multirow[t]{3}{*}{$7-26$} & 2018 & 40.7 & \multirow[t]{3}{*}{$7-25$} & 2018 & 52.4 \\
\hline & 2019 & 50.6 & & 2019 & 65.6 \\
\hline & 2020 & 36.4 & & 2020 & 48.4 \\
\hline \multicolumn{2}{|l|}{ Average } & 42.6 & \multicolumn{2}{|l|}{ Average } & 55.5 \\
\hline \multirow[t]{3}{*}{$7-19$} & 2018 & 50.5 & \multirow{3}{*}{$\begin{array}{l}\text { 4-6 Ussuri } \\
\text { (C) }\end{array}$} & 2018 & 54.2 \\
\hline & 2019 & 60.4 & & 2019 & 65.3 \\
\hline & 2020 & 45.6 & & 2020 & 48.5 \\
\hline \multicolumn{2}{|l|}{ Average } & 52.2 & \multicolumn{2}{|l|}{ Average } & 56.0 \\
\hline \multirow[t]{3}{*}{$7-21$} & 2018 & 50.6 & \multirow[t]{3}{*}{$7-24$} & 2018 & 59.8 \\
\hline & 2019 & 58.4 & & 2019 & 65.4 \\
\hline & 2020 & 48.7 & & 2020 & 55.8 \\
\hline \multicolumn{2}{|l|}{ Average } & 52.6 & \multicolumn{2}{|l|}{ Average } & 60.3 \\
\hline \multirow[t]{3}{*}{$7-28$} & 2018 & 52.0 & \multirow[t]{3}{*}{$7-29$} & 2018 & 60.2 \\
\hline & 2019 & 60.0 & & 2019 & 70.3 \\
\hline & 2020 & 48.0 & & 2020 & 50.8 \\
\hline \multicolumn{2}{|l|}{ Average } & 53.3 & \multicolumn{2}{|l|}{ Average } & 60.4 \\
\hline
\end{tabular}

Water deficiency is a parameter of plants' water regime, which characterizes the water regime plants' stress to a greater extent than the water supply. Water deficiency depends on water supply conditions, as well as meteorological conditions during the day; it occurs in plants on hot days when the moisture amount spent on transpiration exceeds the amount of water coming from the soil. Forms 7-23, 4-6 Ussuri (C) (28\% each) and 7-21 (28.8\%) reacted to the arid growing conditions more than others (Table 2). On average during the years of research, the lowest moisture deficiency at temperature tension and drought was experienced by forms (<20,3\%): (7-25 (16\%), 7-24 (20\%) and 7-27 (20.3\%).

Table 2. Indicators of leaves water deficiency of willow-leafed pear forms for 2018-2020,\%

\begin{tabular}{|c|c|c|c|c|c|}
\hline Specimen & Year & $\begin{array}{c}\text { Water deficiency, } \\
\%\end{array}$ & Specimen & Year & Water deficiency, $\%$ \\
\hline \multirow[t]{3}{*}{$7-25$} & 2018 & 17.6 & \multirow[t]{3}{*}{$7-28$} & 2018 & 26.0 \\
\hline & 2019 & 12.6 & & 2019 & 22.3 \\
\hline & 2020 & 17.8 & & 2020 & 28.1 \\
\hline \multicolumn{2}{|l|}{ Average } & 16.0 & \multicolumn{2}{|l|}{ Average } & 25.5 \\
\hline \multirow[t]{3}{*}{$7-24$} & 2018 & 20.4 & \multirow[t]{3}{*}{$7-19$} & 2018 & 27.6 \\
\hline & 2019 & 16.4 & & 2019 & 20.0 \\
\hline & 2020 & 23.2 & & 2020 & 32.5 \\
\hline \multicolumn{2}{|l|}{ Average } & 20.0 & \multicolumn{2}{|l|}{ Average } & 26.7 \\
\hline \multirow[t]{3}{*}{$7-27$} & 2018 & 20.4 & \multirow{3}{*}{$\begin{array}{l}\text { 4-6 Ussuri } \\
\text { (C) }\end{array}$} & 2018 & 29.8 \\
\hline & 2019 & 18.0 & & 2019 & 22.1 \\
\hline & 2020 & 22.6 & & 2020 & 32.1 \\
\hline \multicolumn{2}{|l|}{ Average } & 20.3 & \multicolumn{2}{|l|}{ Average } & 28.0 \\
\hline \multirow[t]{3}{*}{$7-26$} & 2018 & 22.5 & \multirow[t]{3}{*}{$7-23$} & 2018 & 28.6 \\
\hline & 2019 & 20.0 & & 2019 & 24.0 \\
\hline & 2020 & 24.7 & & 2020 & 31.5 \\
\hline \multicolumn{2}{|l|}{ Average } & 22.4 & \multicolumn{2}{|l|}{ Average } & 28.0 \\
\hline \multirow[t]{3}{*}{$7-29$} & 2018 & 23.4 & \multirow[t]{3}{*}{$7-21$} & 2018 & 30.0 \\
\hline & 2019 & 19.6 & & 2019 & 20.5 \\
\hline & 2020 & 26.5 & & 2020 & 36.0 \\
\hline \multicolumn{2}{|l|}{ Average } & 23.2 & \multicolumn{2}{|l|}{ Average } & 28.8 \\
\hline
\end{tabular}


Water retention capacity serves as a key indicator of plant resistance to moisture deficiency [27]. As a result of the conducted studies, it is established that all forms are characterized by average water retention capacity ( $<51 \%$ ), except form 7-23 (56\% - low drought resistance) (Table 3). In statistical processing, reliable differences in the limit water loss are established between control 4-6 Ussuri and all forms except 7-19, 7-21, 7-24, 7-26, 7-29.

Table 3. Indicators of the limit water loss of willow-leafed pear forms' leaves for 2018-2020, \%

\begin{tabular}{|c|c|c|c|c|c|}
\hline $\begin{array}{l}\text { Specime } \\
\mathrm{n}\end{array}$ & Year & $\begin{array}{l}\text { Limit water loss } \\
\text { in } 6 \text { hours, } \%\end{array}$ & Specimen & Year & $\begin{array}{c}\text { Limit water loss in } 6 \\
\text { hours, } \%\end{array}$ \\
\hline \multirow[t]{3}{*}{$7-25$} & 2018 & 40.0 & \multirow{3}{*}{$\begin{array}{l}\text { 4-6 Ussuri } \\
\text { (C) }\end{array}$} & 2018 & 44.6 \\
\hline & 2019 & 30.2 & & 2019 & 38.4 \\
\hline & 2020 & 45.7 & & 2020 & 59.8 \\
\hline \multicolumn{2}{|l|}{ Average } & 38.6 & \multicolumn{2}{|l|}{ Average } & 47.6 \\
\hline \multirow[t]{3}{*}{$7-28$} & 2018 & 40.1 & \multirow[t]{3}{*}{$7-26$} & 2018 & 50.6 \\
\hline & 2019 & 30.4 & & 2019 & 40.1 \\
\hline & 2020 & 45.8 & & 2020 & 54.4 \\
\hline \multicolumn{2}{|l|}{ Average } & 38.8 & \multicolumn{2}{|l|}{ Average } & 48.4 \\
\hline \multirow[t]{3}{*}{$7-29$} & 2018 & 42.0 & \multirow[t]{3}{*}{$7-27$} & 2018 & 50.4 \\
\hline & 2019 & 39.8 & & 2019 & 42.3 \\
\hline & 2020 & 51.7 & & 2020 & 58.9 \\
\hline \multicolumn{2}{|l|}{ Average } & 44.5 & \multicolumn{2}{|l|}{ Average } & 50.5 \\
\hline \multirow[t]{3}{*}{$7-19$} & 2018 & 45.6 & \multirow[t]{3}{*}{$7-24$} & 2018 & 50.6 \\
\hline & 2019 & 40.0 & & 2019 & 40.0 \\
\hline & 2020 & 51.1 & & 2020 & 62.3 \\
\hline \multicolumn{2}{|l|}{ Average } & 45.6 & \multicolumn{2}{|l|}{ Average } & 51.0 \\
\hline \multirow[t]{3}{*}{$7-21$} & 2018 & 48.6 & \multirow[t]{3}{*}{$7-23$} & 2018 & 56.8 \\
\hline & 2019 & 38,5 & & 2019 & 50.4 \\
\hline & 2020 & 50.9 & & 2020 & 60.8 \\
\hline \multicolumn{2}{|l|}{ Average } & 46.0 & \multirow{2}{*}{\multicolumn{2}{|c|}{ Average }} & 56.0 \\
\hline & & $\mathrm{LCD}_{05}$ & & & 4.6 \\
\hline
\end{tabular}

The results of two-factor dispersion analysis without repetition on the factors "form", "year" for 2018 - 2020 showed reliable differences between the studied forms on all traits with $95 \%$ probability (at $\mathrm{p}<0.05$ ). By the "form" factor, the obtained values of the actual Fisher $\mathrm{F}$ criterion are equal to $11.9-1051,4$ at the theoretical value of criterion $\mathrm{F}_{\text {st. }}-2.46$; by factor "year" it amounted to $15.69-34.78$ at theoretical $F_{\text {st. }}-3.55$. The shares of factors influence obtained as a result of two-factor dispersion analysis are presented in Table 4.

Table 4. Influence of "form" and "year" factors on productivity ( $\mathrm{kg} /$ tree), average weight $(\mathrm{g})$, weight of 1000 seeds $(\mathrm{g})$ of willow-leafed pear forms.

\begin{tabular}{|l|c|c|c|}
\hline \multirow{2}{*}{ Trait } & \multicolumn{3}{|c|}{ Share of influence, \% } \\
\cline { 2 - 4 } & Form & Year & Error \\
\hline Productivity, kg/tree & 64.2 & 24.9 & 10.9 \\
\hline Average weight, g & 99.4 & 0.33 & 0.93 \\
\hline Weight of 1000 seeds, g & 93.2 & 5.4 & 1.4 \\
\hline
\end{tabular}

The dispersion analysis of the willow-leafed pear forms made it possible to establish that the form genotype influence is always higher than that of climatic conditions of the year The form genotype has a maximum effect on the average fruit weight, the weight of 1000 seeds and a minimum effect on productivity; the impact of climatic conditions of the year is maximum for productivity and minimum for average weight.

When isolating the willow-leafed pear forms suitable for future growing as a seed rootstock by seed productivity traits, it is important to consider the biological features of each form's genotype, which is largely determined by the nature of plant variability according to 
a complex of valuable economic traits within the framework of the "genotype environment" interaction.

To assess the conjugacy of recorded traits' variation in the willow-leafed pear forms, we used cluster analysis by Ward method, which is based on the construction of studied objects' groups on the principle of intergroup maximum and intragroup minimum variance (Figure 2 ). The obtained annual average values of three indicators - productivity, average weight, weight of 1000 seeds - made up an informative complex of traits for each of the forms taken into account for 3 years of research.

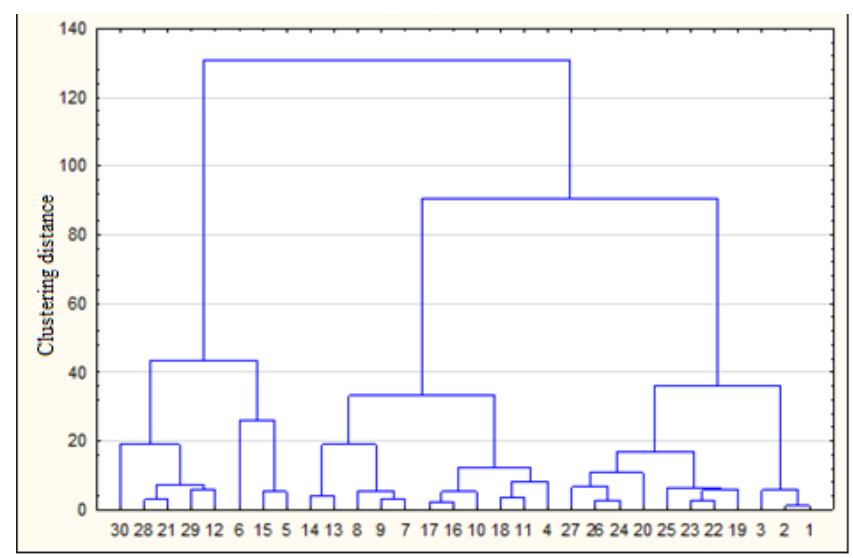

Fig. 2. Results of cluster analysis of willow-leafed pear forms for 2018-2020

Years: $a-2018, b-2019$, c - 2020; forms: 1 - 4-6 Ussuri (C) (a), 2 - 4-6 Ussuri (C) (b), 3 - 4-6 Ussuri (C) (c), 4 - 7-29 (a), 5 - 7-29 (b), 6 - 7-29 (s), 7 - 7-28 (a), 8 7-28 (b), $9-7$-28 (c), 10 - 7-27 (a), 11 - 7-27 (b), 12 - 7-27 (c), 13 - 7-26 (a), 14 - 7-26 (b), 15 - 7-26 (s), 16 - 7-25 (a), 17 - 7-25 (b), 18 - 7-25 (s), 19 - 7-24 (a), 20 - 7-24 (b), 21 - 7-24 (b), $21-7-24$ (s), $22-7-23$ (a), $23-7-23$ (b), $24-7-23$ (c), $25-7-21$ (a), 26 7-21 (b), $27-7-21$ (c), $28-7-19$ (a), $29-7-19$ (b), 30 - 7-19 (c).

As a result of the division into clusters at the level of 60 c.u., we received three groups of forms (in the first -8 forms, in the second and in the third -11 forms). Average values of productivity, average weight, weight of 1000 seeds for each of the selected willow-leafed pear forms' clusters are presented in Table 5.

Table 5. Average indicators values in selected groups of willow-leafed pear forms for 2018-2020

\begin{tabular}{|l|c|c|c|}
\hline \multirow{2}{*}{ Indicator } & \multicolumn{3}{|c|}{ Cluster } \\
\cline { 2 - 4 } & 1 & 2 & 3 \\
\hline Productivity, $\mathrm{kg} /$ tree & 32.87 & 12.09 & 11.82 \\
\hline Average weight, $\mathrm{g}$ & 9.3 & 8.9 & 15.6 \\
\hline Weight of 1000 seeds, $\mathrm{g}$ & 37.29 & 30.46 & 43.19 \\
\hline
\end{tabular}

The average values of the studied indicators in clusters were compared in pairs with the help of the Student's t-criterion. Productivity differs reliably between the first and second clusters $(\mathrm{t}=6.41$ at $\mathrm{p}<0.01)$, and between the first and third clusters $(\mathrm{t}=7.13$ at $\mathrm{p}<0.01)$. Average fruit mass has statistically significant differences between the first and third clusters $(\mathrm{t}=3.93$ at $\mathrm{p}<0.01)$, second and third clusters $(\mathrm{t}=5.59$ at $\mathrm{p}<0.01)$. The weight of 1000 seeds differs significantly between the first and second clusters $(t=2.42$ at $p<0.01)$, second and third clusters $(\mathrm{t}=7.47$ at $\mathrm{p}<0.01)$.

The forms included in the first cluster are characterized by the highest productivity: $7-19$ (2018-2020) - 25-40 kg/tree, 7-24 (2020) - $30 \mathrm{~kg} /$ tree, 7-27 (2020) - 30 kg/tree, 7-29 
(2019), 7-29 (2020) - $50 \mathrm{~kg} /$ tree, 7-26 (2020) - $30 \mathrm{~kg} /$ tree. The data obtained suggest that forms 7-19 and 7-29 produce maximum yields over 3 years of research. The average productivity is possessed by forms that are included in the second cluster: 7-26 (2018-2019), 7-25 (2018-2020), 7-27 (2018-2019), 7-29 (2018). Due to the similarity of genotype variability to external conditions (proximity of variation dynamics to more productive samples), form 7-28 with relatively low indicator - on average $5 \mathrm{~kg} /$ tree for 3 years - is included in the II cluster.

The fruit weight is a hereditary trait and depends on climatic factors of the environment during vegetation, agrotechnics and crop load [28]. All studied willow-leafed pear rootstock forms have very small fruits (less than $25 \mathrm{~g}$ ) according to the classification of fruits size [29]. High values of average weight (15.6 g) are noted for the III cluster (Table 4), which included forms 7-21 (2019-2020), 7-23 (2018-2020), 7-24 (2018-2019), 7-21 (2018), 4-6 Ussuri (2018-2020).

In our studies, there is a noticeable trend in $80 \%$ of the studied forms to reduce the size of pear fruits in arid and hot growing conditions of 2018 and 2020 and increase in wetter 2019. At the same time, the manifestation degree of the change in the fruit weight depended on the reaction of a specific form to various combinations of heat and moisture supply of the growing season. Thus, the increase in fruit weight in 2019 compared to 2018 and 2020 in forms was 7-26: 2.2 - 6.7\%, 7-27: 6.2 - 8.1\%, 7-19: 9.6 - 14.5\%.

According to the data presented in Table 4, the largest weight of 1000 seeds were recorded in cluster forms I and III with values of $37.29 \mathrm{~g}$ and $43.19 \mathrm{~g}$. In most rootstock forms, the weight of 1000 seeds significantly increases during dry growing periods, for example, in a humid and cooler summer period of 2019 in forms 7-21, 7-27 the weight of 1000 seeds amounted to $46.6 \mathrm{~g}$ and $31.6 \mathrm{~g}$ respectively, and in the arid and hot conditions of 2020 it was $49.2 \mathrm{~g}$ and $37.9 \mathrm{~g}$ respectively.

Elite forms differ in seed productivity as well. The difference between the studied forms' seeds is in coloration from light brown to dark brown, almost black, size and shape. Data analysis on seed productivity of willow-leafed pear forms showed that the average number of seeds in 1 fruit ranged from 3.5 (7-27) to 7.2 pieces (7-19). High seed productivity of more than 6 seeds in one fruit for 3 years was noted in the following samples: 7-19 (7.0 -7.2 pcs.), 7-24 (7.1-7.5 pcs.) (Figure 3).

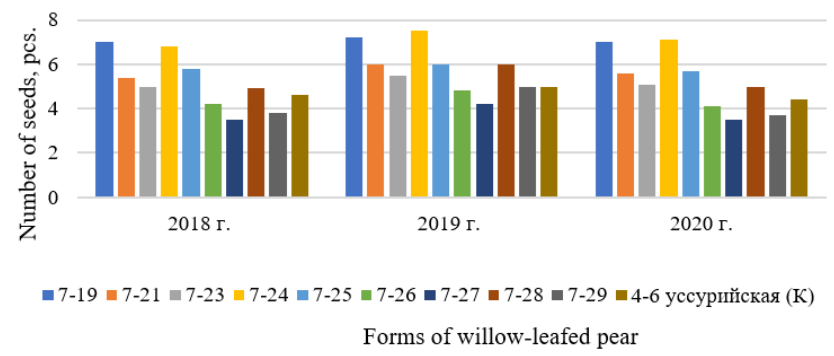

Fig. 3. The number of selected seeds from one fruit in the willow-leafed pear forms for 2018-2020

\section{Conclusion}

High degree of winter resistance in the field conditions of the Orenburg region was revealed in all studied willow-leafed pear forms. Considering that the willow-leafed pear's potential to arid conditions is higher than that of the Ussuri pear, it can be concluded that the economic 
and biological features of elite forms of willow-leafed pear correspond to conditions of extremely continental climate of the research region.

It was established that the following forms are characterized by high productivity: 7-24 (24.0 kg/tree), 7-27 (24.5 kg/tree), 7-19 (32.5 kg/tree) and 7-29 (40.0 kg/tree). It was revealed that stable high seed productivity of more than 6 seeds in one fruit for 3 years was observed in samples 7-19 (7.0 -7.2 pieces), 7-24 (7.1-7.5 pieces). The largest weight of 1000 seeds was noted in forms 7-19 (44.2 g), 7-21 (47.9 g), 7-23 (44.9 g), 7-24 (42.4 g).

A comprehensive assessment of adaptability and seed productivity showed that forms 7 19, 7-24 and 7-29 have the best performance. These forms should be recommended as seed rootstocks for the conditions of the steppe zone of the Southern Urals (on the example of the Orenburg region).

\section{References}

1. V. A. Gryazev, Nursery gardening, 382 (2011)

2. E. N. Sedov, Pear selection, 254 (1997)

3. A. I. Lokhova, A. M. Rusanov, O. E. Merezhko, A. A. Mushinsky, Bulletin of Orenburg State Agrarian University, 6(86), 95 (2020)

4. O. E. Merezhko, G. R. Mursalimova, Fruit growing and berry growing of Russia, 42, 284 (2015)

5. V. I. Avdeev, Bulletin of Orenburg State Agrarian University, 6(74), 60 (2018)

6. V. I. Kashin, E. Z. Savin, Horticulture in the Southern Urals, 488 (2004)

7. P. M. Pechenkin, F. M. Gasymov, Achievements of science and technology of the AIC, 5, 41 (2011)

8. I. V. Semin, E. A. Dolmatov, Z. E. Ozherelieva, Vegetables of Russia, 5, 75 (2020)

9. L. R. Brewer, J. W. Palmer, Acta Hortic, 909, 105 (2011)

10. A. D. Webster, Acta Hortic, 475, 135 (1998)

11. A. D. Webster, Acta Hortic, 622, 499 (2003)

12. S. J. Wertheim, Acta hortic, 596, 299 (2002)

13. R. A. Stern, Scientia Horticulturae, 119(3), 252 (2009)

14. R. A. Stern, I. Doron, G. Redel, A. Raz, M. Goldway, D. Holland Scientia Horticulturae, 161(24), 293 (2013)

15. I. V. Michurin, The best frost-resistant rootstock for pear, 4, 254 (1948)

16. N. I. Savelyev, V. N. Makarov, V. V. Chivilev, M. Yu. Akimov, Pear. Source material, genetics, selection, 160 (2006)

17. K. G. Karychev, A. I. Yankova, I. P. Savenko, R. K. Karychev, The in situ/ex situ rootstock gene pool and its use in the fruit growing of Kazakhstan, 102 (2002)

18. A. I. Lokhova, E. Z. Savin, T. V. Berezina, O. E. Merezhko, Fruit growing and berry growing of Russia, 63, 175 (2020)

19. P. V. Kuznecov, For Michurinsk fruit growing, 6, 31 (1938)

20. P. V. Kuznecov, Soviet Botany, 1-2, 103 (1941)

21. L. A. Apoyan, Horticulture, 12, 18 (1969)

22. G. V. Trusevich, Production of seed and vegetatively reproductible rootstocks on an industrial basis: paper thesis, 42 (1973) 
23. E. Z. Savin, O. E. Merezhko, G. R. Mursalimova, Bulletin of the Orenburg University, 6, 52 (2013)

24. E. Z. Savin, O. E. Merezhko, Bulletin of Uro RAS, 2, 1 (2019)

25. E. N. Sedov, Program and methodology of variety study of fruit, berry and nut crops, 608 (1999)

26. G. A. Lobanov, Program and methodology of variety study of fruit, berry and nut crops, 492 (1973)

27. D. H. Zhang, V. K. Tokhtar', Scientific gazette of Belgorod State University. Series: Natural Sciences, 9(104), 43 (2011)

28. A. I. Lokhova, E. Z. Savin, A. M. Rusanov, A. A. Mushinskiy, Fruit growing and berry growing of Russia, 62, 39 (2020)

29. T. Yu. Kozhevnikova, Ecological assessment of pear seed rootstocks in the conditions of the Saratov region, 22 (2006) 